g.scott-smith@zeeland.nl

Commissioned: 700

\title{
Congress for Cultural Freedom
}

The purpose of the Congress for Cultural Freedom (CCF) was to build a transnational network of anti-Stalinist intellectuals and scholars for the cause of defending freedom of thought and expression. Its inaugural meeting was held during 26-29 June 1950 in the Titaniapalast, a cinema in West Berlin, and soon afterwards it established a permanent Secretariat in Paris. In the late 1960s it was revealed via the New York Times that the CCF had received large-scale funding from the Central Intelligence Agency, and the resulting scandal forced many original members to resign and its name to be changed to the International Association for Cultural Freedom (IACF). Grants from the Ford Foundation sustained the IACF for several more years, but in 1979 it too was closed down.

From the Paris Secretariat the CCF functioned through various associated national bodies (American Committee for Cultural Freedom, British Society for Cultural Freedom). Its political outlook was centre-right / centre-left, and in its promotion of an anti-communist consensus it opposed neutralism in the West as much as Soviet repression in the East. It was also predominantly a transatlantic network, with the main goal being to establish strong bonds between European and American intellectuals. Of the 21 nationalities represented at the inaugural conference, only two were non-European. However, greater attention was given to developing contacts in the Third World from the late 1950s onwards due to the strategic impact of decolonisation. Between 1951-1966 the CCF organised major conferences and seminars in Bombay, Rangoon, Mexico City, Tokyo, Ibadan, Canberra, Cairo, Khartoum, Freetown, Dakar, Manila, Montevideo, Nairobi, and Kuala Lumpa.

The CCF's importance as a transnational institution, and its lasting legacy, stem largely from two sources. Firstly, there was its structural power as a well-funded organiser among the postwar intelligentsia. Alongside the conferences and book publications, great emphasis was placed on creating and sponsoring high-quality scholarly journals in several different countries. The aim was to use the journals as a means to attract and maintain an intellectual community sympathetic to the central principals of the CCF. Significantly, these publications generally sought to avoid direct intellectual combat with left-wing and communist detractors, with editorials choosing instead a middle-ground position and a mix of political analysis and cultural review essays ensuring a broader public appeal. Most notorious was Encounter in London, but other prominent titles in the Congress stable were Preuves (French), Temp Presente (Italian), Der Monat (German), Cuardernos (Spanish), Quest (India), Quadrant (Australia), and Soviet Survey (later Survey). Some, such as Minerva and China Quarterly, are still in print.

Secondly, in the context of the Cold War, there is the role of the CCF as a normative institution. This is particularly evident in its support for the End of Ideology hypothesis. Emerging in the mid-1950s from the combined work of Frenchman Raymond Aron and the Americans Daniel Bell, Edward Shils, and Seymour Martin Lipset, the End of Ideology position claimed that politics should no longer be defined as a contest between rival ideological movements of the right or the left. Instead, the common forces of industrialisation were causing both democratic capitalist and authoritarian collectivist systems to adopt similar methods of socio-economic, technocratic management. The CCF promoted the view that the 
increasing application of scientific methods to social problems needed to be assessed, especially in terms of their success, efficiency, and implications for democracy, individuality, and freedom. This effectively sought to shift the debate away from simplistic observations on East-West competition, thereby claiming greater scholarly merit and opening up a dialogue with a wider audience. The CCF's Future of Freedom conference held in Milan in September 1955, at which Aron, Bell, and Shils participated, was the headline event in this movement. It was followed by seminars in Europe, Africa, and the Far East which focused on the relevance of these developments for the newly-independent, industrialising states in Asia and Africa.

\section{Giles Scott-Smith}

\section{Bibliography}

Coleman, Peter. The Liberal Conspiracy: The Congress for Cultural Freedom and the Struggle for the Mind of Postwar Europe. New York: Free Press, 1989.

Grémion, Pierre. Intelligence de L'anticommunisme: Le Congrès pour la Liberté de la Culture à Paris 1950-1975. Paris, Fayard, 1995.

Scott-Smith, Giles. The Politics of Apolitical Culture: The Congress for Cultural Freedom, the CIA, and Postwar Hegemony. London: Routledges, 2002.

Stonor Saunders, Frances. 1999. Who Paid The Piper? The CIA and the Cultural Cold War. London: Granta.

Actual: 727

Cross references

Pugwash 